\title{
Do Tourism Activities and Urbanization Drive Material Consumption in the OECD Countries? A Quantile Regression Approach
}

\author{
Taiwo Temitope Lasisi ${ }^{1,2}\left(\mathbb{D}\right.$, Kayode Kolawole Eluwole ${ }^{1} \oplus$, Uju Violet Alola ${ }^{3,4}{ }^{(}$, Luigi Aldieri ${ }^{5, *} \mathbb{D}$, Concetto \\ Paolo Vinci ${ }^{5}$ (D) and Andrew Adewale Alola ${ }^{6}$ (D) \\ 1 School of Tourism and Hotel Management, Bahcesehir Cyprus University, Lefkoşa 99010, Turkey; \\ taiwo.lasisi@baucyprus.edu.tr (T.T.L.); kayode.eluwole@baucyprus.edu.tr (K.K.E.) \\ 2 Department of Innovation and International Management, Southern Federal University, \\ 344006 Rostov-on-Don, Russia \\ 3 Department of Tourism Guidance, Istanbul Gelisim University, Istanbul 34310, Turkey; \\ uvalola@gelisim.edu.tr \\ 4 Department of Economics and Management, South Ural State University, 454080 Chelyabinsk, Russia \\ 5 Department of Economic and Statistical Sciences, University of Salerno, 84084 Fisciano, Italy; cpvinci@unisa.it \\ 6 Department of Economics and Finance, Istanbul Gelisim University, Istanbul 34310, Turkey; \\ aadewale@gelisim.edu.tr \\ * Correspondence: laldieri@unisa.it
}

\section{check for} updates

Citation: Lasisi, T.T.; Eluwole, K.K.; Alola, U.V.; Aldieri, L.; Vinci, C.P.; Alola, A.A. Do Tourism Activities and Urbanization Drive Material

Consumption in the OECD Countries? A Quantile Regression Approach. Sustainability 2021, 13, 7742. https://doi.org/10.3390/ su13147742

Academic Editor: Francesco Caracciolo

Received: 11 June 2021

Accepted: 7 July 2021

Published: 12 July 2021

Publisher's Note: MDPI stays neutral with regard to jurisdictional claims in published maps and institutional affiliations.

Copyright: (c) 2021 by the authors. Licensee MDPI, Basel, Switzerland. This article is an open access article distributed under the terms and conditions of the Creative Commons Attribution (CC BY) license (https:// creativecommons.org/licenses/by/ $4.0 /)$.

\begin{abstract}
The United Nations Sustainable Development Goals (UNSDGs) elaborately encompass a global goal for sustainable consumption and production (Goal 12: SDGs), thus providing potential drivers and/or pathways to attaining sustainable consumption. In view of this global goal, this study examined the role of real income per capita, urbanization and especially inbound tourism in domestic material consumption for the panel of OECD countries. The study is conducted for the period of 1995 to 2016 by employing the panel quantile approach. Interestingly, an inverted U-shaped relationship between outbound tourism and domestic material consumption is established across the quantiles, thus indicating that sustainable domestic consumption is achievable after a threshold of domestic material consumption is attained. In addition, achieving sustainable consumption through economic or income growth is a herculean task for the OECD countries because the current reality indicates that income growth triggers higher consumption of domestic materials. However, the results suggest that urbanization is a recipe for sustainable domestic consumption since there is a negative and significant relationship between the two parameters across the quantiles. Nevertheless, the study presents relevant policy for efficient material and resources utilization and that is suitable to drive the SDGs for 2030 and other country-specific sustainable ambitions.
\end{abstract}

Keywords: sustainable consumption; domestic materials; real income; international tourism; quantile regression; OECD

\section{Introduction}

Over the last few years, economy-wide material flow accounts (EW-MFA) have been extended to identify the global use of raw materials linked to with a country's final consumption [1]. Such consumption-based accounts reinforce production-based MFA indicators and take into account the upstream material requirements of imported products in addition to the domestically produced materials. According to the European Commission [2], domestic material consumption (DMC) is the main indicator in MFA, and it is recognized as a key predictor for resource use and efficiency. To actualize the sustainable development goals (SDGs), one of the key factors is resource efficiency, especially for transitional nations [3]. Dong et al. [4] stated that with rapid occurrence of urbanization, industrialization, and economic growth, it is imperative to identify the driving forces of 
resource utilization and exploration in order to strategize advance an innovative measure to ensure resource efficiency which is in line with the number 12 SDG goal on responsible consumption and production. The SDG 12 is one of the main drivers for restructuring which is applicable to all SGDs and supports objectives related to resource use and efficiency across all SDGs. The goal also delineates essential prerequisites to ensure resource sustainability (economic, natural, social, and human capital).

According to a report by theOrganization for Economic Co-operation and Development, OECD [5], DMC and domestic extraction used (DEU) are both following similar trends in the OECD area, with the DEU stabilizing in the early 2000s and growing between 1980 and 2008 by $23 \%$. The composition of material consumption and extraction are comparable in OECD countries except that, due to significant imports, fossil energy accounts for a marginally larger share of consumption than extraction. With respect to the regional share in the OECD countries, the share of consumption of the OECD Americas region is slightly lower that the share of extraction, while the inverse is true for the OECD Europe region. The share of extraction of the Asia-Pacific OECD region is the same as the share of consumption. Telega and Telega [6] categorized five drivers of DMC: topography, climate, demography (including population density), and flow of infrastructure investments, as well as structural, technology, and institution (including behavioral and lifestyle factors) changes. Also, the strong relationship between construction, infrastructure, investment, and economic growth causes increase in material use [7]. In addition to these, we argue that economic development, urbanization (which can occur due to population growth), and tourism inflow can also affect DMC.

Thus, in this study, the determinants of domestic material consumption as paths to sustainable consumption are examined from the perspective of real income, urbanization and outbound tourism to OECD countries. This is based on the fact that the 2020 OECD/European Commission report that noted that "countries with higher gross domestic product (GDP) per capita, seem to have higher urbanization rate, particularly with respect to metropolitan populations." Moreover, economic growth in the OECD is projected to be moderately stable between 2017 and 2060 at just under $2 \%$ on average. However, global material use is expected to be almost twice its 2017value, increasing to 167 gigatonnes (Gt) from $89 \mathrm{Gt}$ in 2016. Importantly, inbound tourism is employed in this case as one of the rare studies that has linked tourism with domestic material consumption. In addition, since 2014, tourism growth in the OECD countries has surpassed the global average, after a period of significant growth in recent years. According to Lasisi et al. (2020); OECD (2020), OECD countries are among the top destinations in the world for tourism, and constitute more than $50 \%$ of travel receipts and global arrivals. The extraction and depletion rate of renewable and non-renewable resource stocks is currently high and is associated with environmental burden, which makes it imperative to determine if economic growth, urbanization, and tourism play a role in domestic material consumption. In this way, our study aims to answer the questions:

(a) Is economic expansion positively associated with domestic material consumption in OECD countries?

(b) Is urbanization positively associated with domestic material consumption in OECD countries?

(c) Is tourism development positively associated with domestic material consumption in OECD countries?

Moreover, until now, no study has established either a U- or an inverted U-shaped relationship between the two parameters (tourism and domestic material consumption) which is billed to make a significant contribution to the body of knowledge.

The remaining section of the study includes the review of the previous and related literature in section two, a description of the data source and methodology in Section 3, an explanation of the results in Section 4, and the presentation of the concluding remarks in Section 5 . 


\section{Literature Review}

\subsection{Domestic Material Consumption}

The domestic material consumption (DMC) quantifies the aggregate amount of the materials diametrically used by a country. It is based on economy-wide material flow accounts (EW-MFA) and according to Eurostat [8], provides an indicator of nations' comparable material consumption with respect to population. It is expressed as the as direct material input (DMI) excluding exports (physical). The DMI quantifies the direct input of materials used in the nation's economy and equals the domestic extraction (DE), plus all exports (physical). The purpose of the indictor is to provide a foundation to decouple economic growth from natural resource use to accomplish a decrease in the degradation of the environment from waste disposal, manufacturing, material processing, and primary production [9]. DMC is categorized by Steinberger and Krausmann [10] into four categories: construction materials, ores and industrial minerals, biomass, and fossil fuels. The current trajectories of global consumption based on the need of transportation of goods and people, working environments, conducive living, and food are categorized to utilization and exploitation and, according to De Jong et al. [11], are deemed unsustainable and should be stopped.

Several studies have tried to determine the impact of different consumption activities on the environment [12-14]. Studies have it that food (grains, vegetables, poultry, dairy, and beef), mobility (airplanes, motorcycle, and cars) as well as use of energy in factories, offices, and homes, and demolition and construction cause the most environmental impacts and, according to Tukker and Jansen [15], constitute about $80 \%$ of ecological footprints. De Jong et al. [11] and Malik et al. [16] opined that environmental impacts are evident in the context of global warming, causing loss of biodiversity, desert encroachment, conflicts, droughts, flooding, destructive storms, and a rise in sea levels. To reduce ecological footprints and address climatic change, it is expedient that there be a shift in lifestyle and consumption patterns at the individual, community, and national levels. This has resulted in the development of new paradigms and concepts like green agriculture, green economy, low carbon development, smart growth, etc. [17].

\section{2. $D M C$ and Economic Expansion}

According to Schandl et al. [13], per capita consumption and per capita income have been linked as global drivers of material use. With respect to economy and DMC, the economic aspect entails production and consumption, resulting in the import and export of goods and services via international trade [18]. This insinuates that the extent of depletion of natural resources is dependent on economic structure, and therefore economic structure establishes the socio-political effects of natural resource management including environmental regulations and policies, research and development, innovation, and technology $[19,20]$.

Canas, Ferrao, and Conceicao [21], using data from 1960 to 1988 from 16 industrialized countries studied the nexus between the direct material input (DMI) (domestic extraction plus imported materials) and income. Their findings suggest that there is an $\mathrm{N}$-shaped nexus between DMI and income, and also that it is in congruence with the EKC hypothesis which was similar to the findings of Bringezu, Schütz, Steger, and Baudisch [22]. A two-decade study of the DMC and DMI of 15 EU countries starting in 1990 by Vehmas, Luukkanen, and Kaivo-Oja [23], reported EKCs for the whole 15 EU with regards to DMC, and only EKC with regards to DMI in Germany. A study to examine the nexus between DMC and economic growth from 39 countries (developing and developed countries) between 1970 and 2005 was carried out by Steinberger, Krausmann, Getzner, Schandl, and West [24]. Their findings show a weak indication for an EKC of DMC as well as an inverted U-shaped association between DMC per capita and GDP per capita. Although this relationship is not statistically significant, other studies such as Schaffartzik et al. [25]; Schandl et al. [13]; Steger and Bleischwitz [26]; Steinberger, Krausmann, 
and Eisenmenger [27]; and Wiedmann et al. [28] have found that income levels are a key determining factor of material use.

Other relevant literature regarding material flow analysis and the EKC hypothesis includes Dittrich, Giljum, Lutter, and Polzin [29]; Giljum, Dittrich, Lieber, and Lutter [30]; Schaffartzik et al. [25]; Schandl et al. [13]; and Steinberger et al. [27]. These studies have emphasized the influence of structural factors like endowment of different material resources, population density, country size, and development trajectory differences between low-income nations and emerging economies as tangible net resource exporters. Steinberger et al. [27] found a short-term coupling between economic development and material resource flows. We therefore posit that:

Hypothesis 1 (H1). Economic expansion is positively associated with domestic material consumption.

\subsection{DMC and Urbanization}

According to Piña and Martínez [31], the urbanization process has moved beyond traditional human settlements and now involves the development of large urban expanses following the growing need for environmental goods and services, as well as the upsurge in the production of waste and emissions. Therefore, it is imperative to understand how urbanization has impacted resource flows into cities as well as outputs such as services, products, and waste. According to Decker et al. [32], there are three inputs of urbanization: (a) construction and waste; (b) transformed inputs (fuel, food, and water) which are probably the most significant materials imported to the urban system; and (c) passive inputs (heat, water, and air).

Analyses of urban energy and material flows apply industrial ecology to the assessment and quantification of specific material flows (e.g., food, nutrients, and raw materials) and energy as they build up and egress the urban system, thereby affecting the environment [33,34]. Different studies have explored this approach. For instance, Moore, Kissinger, and Rees [35] integrated urban metabolism with ecological footprint analysis and residential consumption of the Vancouver metropolitan district for the year 2006. Also, Sahely et al. [36] investigated the urban metabolism of the Greater Toronto Area between 1987 and 1999 to analyze waste management, material cycling, infrastructure, and energy efficiency in urban systems. Barles [37] examined the feasibility of material flow analysis both at the urban and regional scales in France for the year 2003; their findings show that the relations between material flows and regional and urban planning and development are of significant importance. With expanding globalization and increasing international competition for investment, metropolitan regions will lead to increase in passive input, transformed input and construction as well as waste, so we hypothesize that:

Hypothesis 2 (H2). Urbanization is positively associated with domestic material consumption.

\subsection{DMC and Tourism Development}

Undoubtedly, tourism is a key economic driver. The industry has impact on different sectors such as transportation, accommodation, food and beverages, entertainment, and related industries (tour agent, tour operators, travel agencies, etc.). Tourism development leads to increases in infrastructure construction, population, and the three inputs of urbanization suggested by Decker et al. [32]. Several studies have affirmed that the activity in the tourism industry affects energy [38-42], carbon emission [43,44], and income [45,46]; yet very few studies have investigated the relationship between tourism and domestic material consumption. Li et al.'s [33] study on Beijing tourism highlighted that the Olympics increased business and tourism travel to the country. They also mentioned that construction activity and tourism development before the Olympic Games attracted a large number of migrant workers that has resulted in large resource consumption and waste emissions.

Furthermore, European cities such as Vienna, Hamburg, Paris, and Madrid are heavily depend on modern manufacturing, services, and tourism. Therefore, they have a high 
efficiency of resource-use and low material consumption per capita. According to a report by Giljum and Dittrich [47], the Seychelles' primary industry is tourism and due to the rapid expansion of tourism, the material consumption of the country has experienced a high growth rate. Also, the upstream flow of total material consumption (TMC) per capita is more than thrice the DMC per capita, which is principally because of imported biomass, especially of products like beer, wine, spirits, oil, fats, and processed foods (e.g., pasta); which are presumed to me mostly used within the tourism industry. We therefore posit that:

Hypothesis 3 (H3). Tourism development is positively associated with domestic material consumption.

Considering the discussion of the aforementioned related studies, a summary and inferences of the studies are presented in Table 1. Moreover, while considering the gap in the extant studies, the aforementioned hypotheses are inferred with an implied conceptual approach in Figure 1.

Table 1. Synopsis of the Literature Review.

\begin{tabular}{|c|c|c|c|c|}
\hline Reference & Year & Country & Variables & Outcome \\
\hline $\begin{array}{l}\text { Canas, Ferrao, and } \\
\text { Conceicao [21] }\end{array}$ & 1960-1998 & $\begin{array}{l}16 \text { industrialized } \\
\text { countries }\end{array}$ & $\begin{array}{l}\text { Direct Material Input (DMI) per } \\
\text { capita, Gross Domestic Product } \\
\text { (GDP) per capita }\end{array}$ & $\begin{array}{l}\text { Inverted-U, or quadratic } \\
\text { relationship between DMI and } \\
\text { GDP. }\end{array}$ \\
\hline $\begin{array}{c}\text { Vehmas, } \\
\text { Luukkanen, and } \\
\text { Kaivo-Oja [23] }\end{array}$ & 1980-2000 & 15 EU countries & $\begin{array}{l}\text { Direct Material Input (DMI) per } \\
\text { capita, Gross Domestic Product } \\
\text { (GDP) per capita }\end{array}$ & $\begin{array}{l}\text { A weak de-linking of material } \\
\text { flows from economic growth. }\end{array}$ \\
\hline $\begin{array}{l}\text { Steinberger, } \\
\text { Krausmann, } \\
\text { Getzner, Schandl, } \\
\text { and West [24] }\end{array}$ & 1970-2005 & $\begin{array}{l}39 \text { developing and } \\
\text { developed } \\
\text { countries }\end{array}$ & $\begin{array}{l}\text { Direct Material Input (DMI) per } \\
\text { capita, Gross Domestic Product } \\
\text { (GDP) per capita }\end{array}$ & $\begin{array}{l}\text { A weak indication for an EKC of } \\
\text { DMC as well as an inverted } \\
\text { U-shaped association between } \\
\text { DMC per capita and GDP per } \\
\text { capita }\end{array}$ \\
\hline $\begin{array}{l}\text { Moore, Kissinger, } \\
\text { and Rees [35] }\end{array}$ & 2006 & $\begin{array}{l}\text { Metro Vancouver } \\
\text { (North America) }\end{array}$ & $\begin{array}{l}\text { Urban metabolism, } \mathrm{CO}_{2} \\
\text { emissions }\end{array}$ & $\begin{array}{l}\text { Food, transportation, and } \\
\text { buildings are the largest } \\
\text { components of the footprint. }\end{array}$ \\
\hline Barles [37] & 2003 & France & $\begin{array}{c}\text { DMC, Domestic Material Input, } \\
\text { Domestic Material Output, and } \\
\text { Local and Exported Processed } \\
\text { Output }\end{array}$ & $\begin{array}{l}\text { A significant relationship } \\
\text { between material flows and } \\
\text { regional and urban planning and } \\
\text { development. }\end{array}$ \\
\hline Li et al. [33] & $2000-2015$ & Beijing & $\begin{array}{l}\text { Total Material Consumption, } \\
\text { GDP }\end{array}$ & $\begin{array}{l}\text { “Tourism development and } \\
\text { construction activity leading up } \\
\text { to the Olympic Games attracted } \\
\text { a large inflow of migrant } \\
\text { workers." "The resulting huge } \\
\text { resource consumption and waste } \\
\text { emission:" }\end{array}$ \\
\hline $\begin{array}{l}\text { Giljum and Dittrich } \\
\text { [47] }\end{array}$ & 1985-2005 & $\begin{array}{l}16 \text { countries in } \\
\text { Africa, Asia and } \\
\text { Latin America }\end{array}$ & $\mathrm{DMC}, \mathrm{CO}_{2}$ emissions, GDP & $\begin{array}{l}\text { Seychelles' primary industry is } \\
\text { tourism and due to the rapid } \\
\text { expansion of tourism, the } \\
\text { material consumption of the } \\
\text { country has experienced a high } \\
\text { growth rate. }\end{array}$ \\
\hline
\end{tabular}




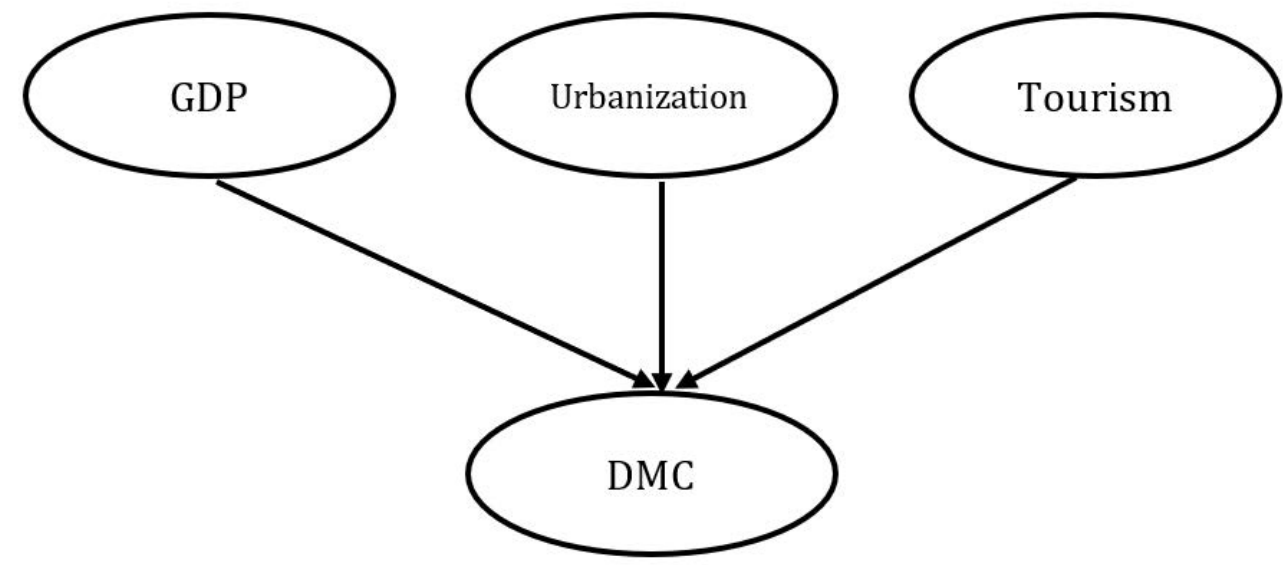

Figure 1. The conceptual approach of the study.

\section{Materials and Methods}

\subsection{Data Description}

This study utilized the panel of 31 selected OECD member countries (Belgium, Czech Republic, Denmark, Finland, Germany, Greece, Hungary, Italy, Japan, Korea Republic (South Korea), Latvia, Lithuania, Luxembourg, Netherlands, Norway, Poland, Portugal, Slovak Republic, Slovenia, Sweden, United Kingdom, Bulgaria, Croatia, Cyprus, Romania, Australia, Austria, Israel, Mexico, New Zealand, and United States.) for the period 1995-2016. In Table 2 (the upper part), detailed information about the employed dataset is presented. As indicated in Figure 1, the domestic material consumption per capita is the dependent variable, while other variables are used as explanatory variables as gross domestic product (GDP) per capita accounts for the unexplained factors. Furthermore, the descriptive statistics of the dataset are illustrated in the lower part of Table 2. In specific, the descriptive statistics revealed that there is a higher deviation in the values of international tourism arrivals, followed by series of GDP deviations. Importantly, there is statistical evidence of correlation between the dependent and explanatory variables as indicated in Table A1 of Appendix A. Moreover, the series are largely stationary after the first difference, as revealed by the result of the unit root tests in Table 3.

Table 2. Data description and statistics.

\begin{tabular}{ccc}
\hline Variable & Description and Unit & Source \\
\hline $\begin{array}{c}\text { Domestic Material } \\
\text { Consumption }\end{array}$ & $\begin{array}{c}\text { Materials used domestically by the economy } \\
\text { (measured in tonnes) }\end{array}$ & OECD \\
\hline Per capita (DMCC) & $\begin{array}{c}\text { Proxy for income per capita and measured as } \\
\text { constant 2010 U.S. dollars }\end{array}$ & WDI \\
\hline Gross domestic product & $\begin{array}{c}\text { Computed as GDP per capita divided by mid-year } \\
\text { country population }\end{array}$ & \\
\hline per capita (GDPC) & $\begin{array}{c}\text { The number of international inbound tourists that } \\
\text { have travelled to another country other than the } \\
\text { usual country of residence }\end{array}$ & WDI \\
\hline $\begin{array}{c}\text { International tourism arrivals } \\
\text { (TOU) }\end{array}$ & $\begin{array}{c}\text { Urban population rate refers to people living in } \\
\text { urban areas as (\% of total population) }\end{array}$ & \\
\hline Urbanization rate (URB) & Mean, Minimum, Maximum, Standard Dev, \\
Skewness, Kurtosis & Jarque- \\
Common Statistics & 13.840, 32.325, 0.891, 6.507, 0.084, 3.220, 1.688 & \\
\hline LDMCC & $\begin{array}{c}\text { 47,602.56, 3955.276, 315,349.5, 50,180.31, 2.599, } \\
10.803,1930.38 ~ A ~\end{array}$ & \\
\hline LGDPC &
\end{tabular}


Table 2. Cont.

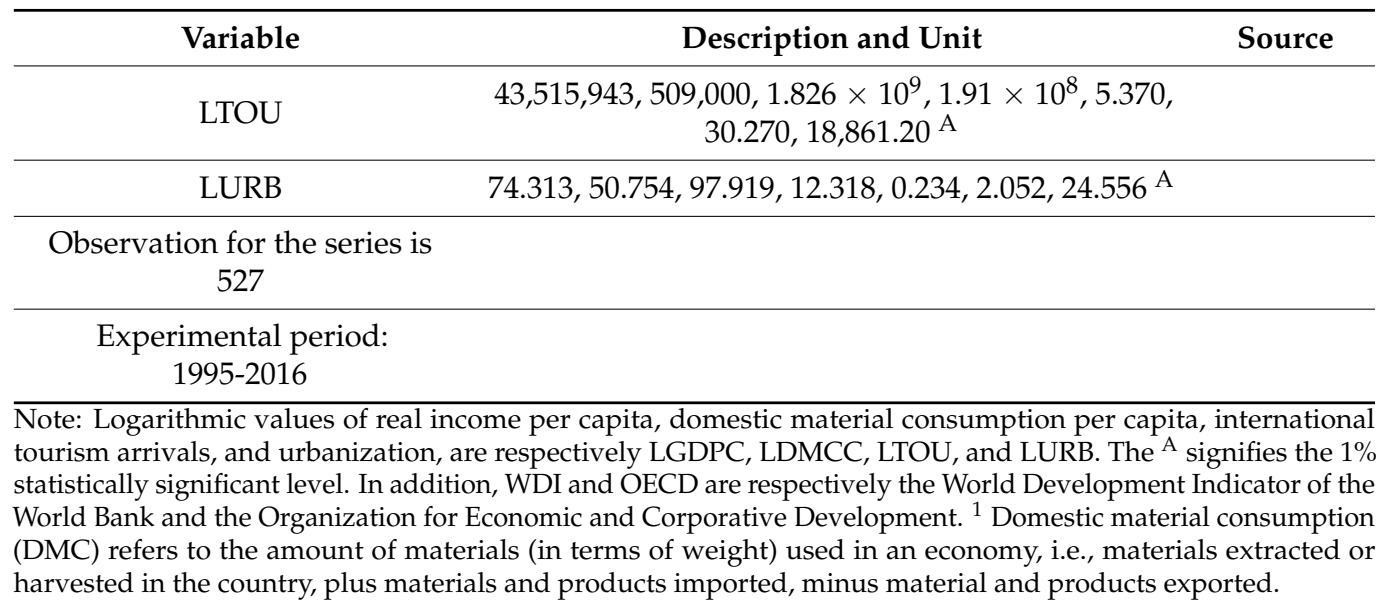

Table 3. Panel unit root test.

\begin{tabular}{|c|c|c|c|c|}
\hline Variable (Level) & LLC & IPS & ADF-Fisher & PP-Fisher \\
\hline LDMCC & $-1.79^{\mathrm{B}}$ & -0.70 & 72.29 & $99.06^{\mathrm{A}}$ \\
\hline LGDPC & $-6.35^{\mathrm{A}}$ & $-1.38^{C}$ & 65.66 & $108.83^{\mathrm{A}}$ \\
\hline LTOU & 3.04 & 6.00 & 29.07 & 25.52 \\
\hline LURB & $-73.19^{\mathrm{A}}$ & $-34.45^{\mathrm{A}}$ & $224.46^{\mathrm{A}}$ & $807.13^{\mathrm{A}}$ \\
\hline Variable $(\Delta)$ & LLC & IPS & ADF-Fisher & PP-Fisher \\
\hline LDMCC & $-9.32^{\mathrm{A}}$ & $-8.73^{\mathrm{A}}$ & $189.90^{\mathrm{A}}$ & $384.69^{\mathrm{A}}$ \\
\hline LGDPC & $-8.34^{\mathrm{A}}$ & $-5.47^{\mathrm{A}}$ & $129.36^{\mathrm{A}}$ & $157.75^{\mathrm{A}}$ \\
\hline LTOU & $-5.92^{\mathrm{A}}$ & $-6.42^{\mathrm{A}}$ & $144.11^{\mathrm{A}}$ & $233.94^{\mathrm{A}}$ \\
\hline LURB & -1.25 & $-6.63^{A}$ & $100.25^{\mathrm{A}}$ & $193.01^{\mathrm{A}}$ \\
\hline \multicolumn{5}{|c|}{ Pedroni Residual Cointegration Test } \\
\hline & \multicolumn{2}{|c|}{ Within Dimension } & \multicolumn{2}{|c|}{ Between Dimension } \\
\hline & \multicolumn{2}{|c|}{ T-Statistic } & $\begin{array}{l}\text { Weighted } \\
\text { Statistic }\end{array}$ & T-Statistic \\
\hline $\begin{array}{c}\text { Group } \\
\text { rho-Statistic }\end{array}$ & \multicolumn{2}{|c|}{0.83} & 0.35 & 1.87 \\
\hline $\begin{array}{c}\text { Panel } \\
\text { rho-Statistic }\end{array}$ & \multicolumn{2}{|c|}{$-2.73^{\mathrm{A}}$} & 0.38 & $-11.93^{\mathrm{A}}$ \\
\hline $\begin{array}{c}\text { Group } \\
\text { PP-Statistic }\end{array}$ & \multicolumn{2}{|c|}{$-12.31^{\mathrm{A}}$} & $-6.68^{A}$ & $-3.07^{\mathrm{A}}$ \\
\hline $\begin{array}{c}\text { Group } \\
\text { ADF-Statistic }\end{array}$ & \multicolumn{3}{|r|}{$-8.83^{\mathrm{A}}$} & $-3.99 \mathrm{~A}$ \\
\hline
\end{tabular}

Kao Residual

Cointegration

\begin{tabular}{cc}
\hline & T-Statistic \\
\hline ADF & $-1.96^{\mathrm{B}}$ \\
\hline
\end{tabular}

Note: Logarithmic values of real income per capita, domestic material consumption per capita, international tourism arrivals, and urbanization, as LGDPC, LDMCC, LTOU, and LURB, respectively. The marks A, B , and $\mathrm{C}$ are the $1 \%, 5 \%$ and $10 \%$ statistically significant levels, respectively. In addition, LLC, IPS, ADF, and PP are the Levin, Lu \& Chu [48], Im, Pesaran \& Shin [49], Augmented Dickey-Fuller, and Phillips-Perron tests, respectively. 


\subsection{Empirical Method}

The pattern of material and/or resource use is found to play a key role in economic development and growth [24,27]. Indicatively, energy sources, technological innovation, and other resources or material related indicators are known fundamentals of economic growth and development [50-55]. Dietz and Rosa [56], Wiedmann et al. [28] and Baynes and Musango [57] illustrated the drivers of the material footprint vis-à-vis domestic material consumption from different perspectives. The current study incorporates international tourism arrivals in the domestic material consumption model and at the same time examines the threshold of tourism arrivals such that the form of the linear functional in the current context is presented as:

$$
\text { LDMCC }=f(\text { LGDPC, LTOU, LTOUsq, LURB) } .
$$

Quantile Regression

After showing the evidence of series stationarity and cointegration (see Table 3), we proceed to investigate the relationship between the implied DMCC and the explanatory variables. Considering the attempt to examine the impact of the explanatory variables on domestic material consumption across the quantile, a panel study was examined from the quantile regression $(\mathrm{QR})$ approach. In specific, $\mathrm{QR}$ considers the entire distribution in addition to its desirability to potentially control time-variant issues of heterogeneity and outliers [58-60]. Moreover, the lack of evidence of a normal distribution for the all the explanatory variables, as revealed in Table 2, is significant evidence that also supports the $\mathrm{QR}$ approach. In addition, QR has the advantage of estimating the complete description other than the conditional mean and median distribution [61]. Hence, the modification of the conditional implements the QR approach such that:

$E\left[L D M C C_{i t} \mid\left(L_{G D P C}{ }_{i t}, L_{T O U}, L_{i T O U} q_{i t} L U R B_{i t}\right), \alpha_{i}\right]=\left(\operatorname{LGDPC}_{i t}^{T}, L T O U_{i t}^{T}, L T O U s q_{i t}^{T}\right) \beta+\alpha_{i}$

such that

$$
\begin{gathered}
Q_{\text {LDMCC }_{i t}}\left[\tau \mid\left(\text { LGDPC }_{i t}, \text { LTOU }_{i t}, \text { LTOUsq }_{i t}, L U R B_{i t}\right), \alpha_{i}\right] \\
=\beta_{1 \tau} L G D P C_{i t}+\beta_{2 \tau} \text { LTOU }_{i t}+\beta_{3 \tau} \text { LTOUsq }_{i t}+\beta_{4 \tau} L U R B_{i t}+\alpha_{i}
\end{gathered}
$$

For all time $t$ and cross-section $i$ are 1995-2016 and $I=1,2,3 \ldots, 31$, respectively, given the unobserved country effect $\alpha_{i}$.

From the conceptual framework of Koenker and Bassett Jr. [62] which is an extension of the conventional least-squares, the application of different conditional quantile functions is extended as a $Q R$ approach such that $\hat{\beta}(\tau)$ in Equation (3) is estimated by $\tau$ th through the following expression

$$
\hat{\beta}(\tau)=\operatorname{argmin}_{\beta \in \Re^{K}}\left[\sum_{i \in\left\{i: y_{i} \geq x_{i} \beta\right\}} \tau\left|y_{i}-x_{i} \beta\right|+\sum_{i \in\left\{i: y_{i}<x_{i} \beta\right\}}(1-\tau)\left|y_{i}-x_{i} \beta\right|\right]
$$

Moreover, the parameter size $\tau$ is quantified as $0<\tau>1$ such that there is a minimization of the weighted sum of absolute deviations. As such, the conditional quantile of the DMCC for all the explanatory variables $x_{i}$ is presented as:

$$
\begin{aligned}
& Q_{D M C C}\left[\tau \mid\left(L_{G D P C}, L_{T O U}, L_{T O U} q_{i}, L U R B_{i}\right)\right] \\
& =\left(L_{G D P C}, L_{T O U}, L_{T O U s}{ }_{i}, L U R B_{i t}\right) \beta_{\tau}
\end{aligned}
$$

In this case, the respective slope parameters for the entire distribution of the LDMCC for each category quantile is evaluated in place of the mean of the conditional distribution of the ordinary least square (OLS) and other related regression approaches. However, the current approach has employed the OLS, the fully-modified OLS (FMOLS), and the dynamic OLS of Phillips \& Hansen [63], such that the results are further compared with the quantile regression estimate as depicted in Table 4. 
Table 4. The ordinary least square and quantile regression with (100) bootstrapping. Dependent variable $=$ CEM .

\begin{tabular}{|c|c|c|c|c|c|c|c|c|c|}
\hline Variable & \multicolumn{3}{|c|}{ OLS } & \multicolumn{3}{|c|}{ FMOLS (Pooled) } & \multicolumn{3}{|c|}{ Dynamic (Pooled) } \\
\hline LGDPC & \multicolumn{3}{|c|}{$0.26^{\mathrm{A}}$} & \multicolumn{3}{|c|}{$0.29^{\mathrm{A}}$} & \multicolumn{3}{|c|}{$0.29^{\mathrm{B}}$} \\
\hline LURB & \multicolumn{3}{|c|}{$-1.26^{\mathrm{A}}$} & \multicolumn{3}{|c|}{$-1.73^{\mathrm{A}}$} & \multicolumn{3}{|c|}{-0.09} \\
\hline LURB & \multicolumn{3}{|c|}{$3.61^{\mathrm{A}}$} & \multicolumn{3}{|c|}{$2.08^{\mathrm{A}}$} & \multicolumn{3}{|c|}{2.47} \\
\hline LTOU & \multicolumn{3}{|c|}{$-0.11^{\mathrm{A}}$} & \multicolumn{3}{|c|}{$-0.07^{\mathrm{A}}$} & \multicolumn{3}{|c|}{-0.09} \\
\hline \multicolumn{10}{|c|}{ Quantile Regression } \\
\hline Variable & 10th & 20th & 30th & 40th & 50th & 60th & 70th & 80th & 90th \\
\hline LGDPC & $0.57^{\mathrm{A}}$ & 0.01 & $-0.02^{\mathrm{A}}$ & $0.07^{\mathrm{C}}$ & $0.11^{\mathrm{A}}$ & $0.14^{\mathrm{A}}$ & $0.15^{\mathrm{A}}$ & $0.18^{\mathrm{A}}$ & $0.21^{\mathrm{A}}$ \\
\hline LURB & $-4.22^{\mathrm{A}}$ & -0.56 & $-0.42^{C}$ & $-0.26^{\mathrm{B}}$ & $-0.20^{\mathrm{B}}$ & $-0.27^{\mathrm{A}}$ & $-0.35^{\mathrm{A}}$ & $-0.05^{\mathrm{A}}$ & $0.32^{\mathrm{B}}$ \\
\hline LTOU & $3.31^{\mathrm{A}}$ & $3.22^{\mathrm{A}}$ & $3.53^{\mathrm{A}}$ & $3.51^{\mathrm{A}}$ & $3.51^{\mathrm{A}}$ & $3.33^{\mathrm{A}}$ & $3.22^{\mathrm{A}}$ & $3.14^{\mathrm{A}}$ & $3.24^{\mathrm{A}}$ \\
\hline LTOUsq & $-0.10^{\mathrm{A}}$ & $-0.10^{\mathrm{A}}$ & $-0.11^{\mathrm{A}}$ & $-0.11^{\mathrm{A}}$ & $-0.11^{\mathrm{A}}$ & $-0.11^{\mathrm{A}}$ & $-0.10^{\mathrm{A}}$ & $-0.10^{\mathrm{A}}$ & $-0.11^{\mathrm{A}}$ \\
\hline Constant & $-12.81^{\mathrm{A}}$ & $-21.26^{\mathrm{A}}$ & $-23.98^{\mathrm{A}}$ & $-24.88^{\mathrm{A}}$ & $-25.23^{\mathrm{A}}$ & $-23.51^{\mathrm{A}}$ & $-22.20^{\mathrm{A}}$ & $-22.97^{\mathrm{A}}$ & $25.15^{\mathrm{A}}$ \\
\hline
\end{tabular}

\section{Results}

As indicated from the QR results in Table 4, this study supports the validity of the threshold of international tourism arrivals (TOU) in the relationship between TOU and domestic material consumption for the panel of the OECD countries. Precisely, TOU exerts a positive and statistically significant impact on domestic material consumption across the quantile. With the impact of TOU on DMCC (across the 10- to 90-quantile) ranging between 3.16 and 3.53, the maximum impact of 3.53 is experienced at the 30-quantile. Indicatively, the study suggests that a $1 \%$ increase in the international tourism arrivals to the panel of OECD countries triggers a maximum of a $3.53 \%$ increase in tonnes of domestic material consumption. Moreover, the impact of the square of TOU on DMCC is negative and statistically significant. This illustrates that, the increase in the international tourism arrivals to the OECD countries diminishes the domestic material consumption after the attainment of the threshold impact resulting from inbound tourism. Importantly, the impact of the square of TOU on DMCC is negative and is almost the same magnitude across the quantiles. Generally, the overall evidence posits an inverted U-shaped relationship between domestic material consumption and international tourism arrivals to OECD member countries. Our findings therefore support the proposed hypothesis which is that for OECD countries, increased tourism leads to increased DMC which is in congruence with findings from Li et al.'s [33] study that suggests that tourism attracts a large number of migrant workers, increase in hotel stays, transportation use, etc. which results in large resource consumption and waste emissions.

In addition, the impact of per capita real income (GDPC) and urbanization (URB) on domestic material consumption is found to be largely positive and negative, respectively, across the quantile. The positive impact of income on DMC supports our hypothesis, while the negative impact of urbanization on DMC opposes our hypothesis. In specific, per capita real income exerts an incremental and significant impact on DMCC especially from the 40-quantile, thus suggesting that the increase in the real income per person of OECD member countries causes increased consumption of domestic materials. The economic rationale is understandable because when the populace access more income or incentives, there is an increased tendency for economic development and growth through the use or consumption of more materials and resources. The existing studies of Steinberger, Krausmann and Eisenmenger [27], Steinberger et al. [24], and Wiedmann et al. [28] support the evidence of the relationship between economic growth and/or economic development 
and material consumption. On the other hand, the impact of urbanization is negative across the quantiles and displays a "rise and fall" pattern. This is in agreement with the study of Bianchi, Tapia \& del Valle [64] that suggests that lower material consumption is potentially associated with large regions, urban agglomerations, and tertiary economies.

Moreover, evidence from the OLS, FMOLS, and the DOLS alluded to the above-stated empirical inference from the QR approach. Specifically, the trio of OLS, FMOLS, and DOLS approaches also established the inverted U-shaped relationship between the international tourism arrivals and domestic material consumption. Additionally, these approaches affirmed the same result with almost the same impact as the $Q R$ approach for the case of per capita real income and urbanization.

\section{Conclusions}

For the first time in the literature, the current study examines the relationship between international tourism arrivals and domestic material consumption. Adding to this novelty, this study illustrates the validity of the inverted U-shaped relationship between inbound tourism (to the OECD member countries) and domestic material consumption. The study implemented per capita real income (GDPC) and urbanization as additional explanatory variables in a panel quantile regression framework over the experimental period of 1995 to 2016. Importantly, the study found that inbound tourism to the panel of OECD countries increased the consumption of domestic materials until a threshold level of consumption was attained. Thereafter, an additional increase in inbound tourism to the OECD countries triggered a decrease in domestic material consumption, thus establishing the inverted U-shaped relationship between inbound tourism and domestic material consumption. In addition, the empirical results illustrate that real income per capita and urbanization affect domestic material consumption in positive and negative trajectories, respectively. The impacts of the real income per capita and urbanization on domestic material consumption were largely significant across the quantiles. This study opens more future research opportunities, especially in the context of (domestic) material consumption. In the future, the impact of inbound tourism on domestic material consumption could focus on specific geographical locations within and between tourist destinations.

\subsection{Policy}

The prospect of attaining sustainable consumption in the OECD countries could be more realistic when income growth and/or economic development yields lower domestic material consumption. Therefore, against the current trend, economic measures that ensure the economic independence and prosperity of the OECD member countries is strongly encouraged. Indicatively, such economic policy will increase the economic means and sustainability of the people as well as their capability to access sustainable consumption without compromising environmental quality. In addition, the inverted U-shaped relationship between tourism arrivals and domestic material consumption is an indication that the approach to tourism activities in the OECD countries is in the right direction. Expectedly, more initiative toward sustainable tourism development among the OECD countries will further enhance the minimal consumption of domestic materials, thus prompting robust sustainable consumption among the member countries. Moreover, our conclusions mirror those from Valeri and Baggio [64], who revealed through social network analysis (SNA) that aspects of tourism have potential to accommodate sustainable pathways. Thus, the integrated consumption, operational, and managerial aspects of tourists and tourism providers: travel agencies, tour operators, restaurants and hospitality, and others should be further developed.

\subsection{Limitation and Recommendation for Future Study}

As a limitation, the country selection for the current study was based on data availability instead of employing the tourist destinations or the top material consuming countries of the OECD member states. As such, future studies could be dedicated to exploring the same 
research question but for the OECD member states that are tourist destinations or/and topranked material consumption countries. Additionally, by leveraging the SNA [64], related aspects of tourism industry could be explored under the framework of material consumption.

Author Contributions: Formal analysis, investigation, methodology, T.T.L., K.K.E. and U.V.A.; writing-review and editing, L.A., C.P.V. and A.A.A. All authors have read and agreed to the published version of the manuscript.

Funding: This research received no external funding.

Institutional Review Board Statement: Not applicable.

Informed Consent Statement: Not applicable.

Data Availability Statement: Data available in a publicly accessible repository.

Conflicts of Interest: The authors declare no conflict of interest.

\section{Appendix A}

Table A1. The correlation matrix.

\begin{tabular}{ccccc}
\hline Variable & LDMCC & LGDPC & LTOU & LURB \\
\hline LDMCC & 1.00 & & & \\
LGDPC & $-0.16^{\mathrm{A}}$ & 1.00 & & \\
LTOU & $-0.26^{\mathrm{A}}$ & $0.12^{\mathrm{A}}$ & 1.00 & 1.00 \\
LURB & $-0.14^{\mathrm{A}}$ & $0.60^{\mathrm{A}}$ & 0.01 & \\
\hline
\end{tabular}

Note: Logarithmic values of real income per capita, domestic material consumption per capita, international tourism arrivals, and urbanization, are LGDPC, LDMCC, LTOU, and LURB, respectively. The mark ${ }^{\mathrm{A}}$ represents the $1 \%$ statistically significant level.

\section{References}

1. Fischer-Kowalski, M.; Krausmann, F.; Giljum, S.; Lutter, S.; Mayer, A.; Bringezu, S.; Moriguchi, Y.; Schütz, H.; Schandl, H.; Weisz, $\mathrm{H}$. Methodology and indicators of economy-wide material flow accounting: State of the art and reliability across sources. J. Ind. Ecol. 2011, 15, 855-876. [CrossRef]

2. European Commission. Roadmap to a Resource Efficient Europe (Communication from the Commission to the European Parliament, the Council, the European Economic and Social Committee and the Committee of the Regions No. COM(2011) 571 Final); European Commission: Brussels, Belgium, 2011.

3. Mezger, G.; del Tánago, M.G.; De Stefano, L. Environmental flows and the mitigation of hydrological alteration downstream from dams: The Spanish case. J. Hydrol. 2020, 598, 125732.

4. Dong, L.; Dai, M.; Liang, H.; Zhang, N.; Mancheri, N.; Ren, J.; Dou, Y.; Hu, M. Material flows and resource productivity in China, South Korea and Japan from 1970 to 2008: A transitional perspective. J. Clean. Prod. 2017, 141, 1164-1177. [CrossRef]

5. OECD. Material Resources, Productivity and the Environment: Key Findings; OECD: Paris, France, 2013.

6. Telega, I.; Telega, A. Driving factors of material consumption in European countries-Spatial panel data analysis. J. Environ. Econ. Policy 2019, 9, 269-280. [CrossRef]

7. OECD. Global Material Resources Outlook to 2060: Economic Drivers and Environmental Consequences; OECD: Paris, France, 2018.

8. OECD/European Commission. Cities in the World: A New Perspective on Urbanisation; OECD/European Commission: Paris, France, 2020.

9. OECD. OECD Tourism Trends and Policies 2020; OECD: Paris, France, 2020; ISBN 9789264703148.

10. Lasisi, T.T.; Alola, A.A.; Eluwole, K.K.; Ozturen, A.; Alola, U.V. The environmental sustainability effects of income, labour force, and tourism development in OECD countries. Environ. Sci. Pollut. Res. 2020, 27, 21231-21242. [CrossRef] [PubMed]

11. Eurostat Material Flow Accounts and Resource Productivity. Available online: https://ec.europa.eu/eurostat/statisticsexplained/index.php?title=Material_flow_accounts_and_resource_productivity (accessed on 15 May 2021).

12. United Nations. Domestic Material Consumption; United Nations: New York, NY, USA, 2017.

13. Steinberger, J.K.; Krausmann, F. Material and energy productivity. Environ. Sci. Technol. 2011, 45, 1169-1176. [CrossRef] [PubMed]

14. De Jong, M.; Joss, S.; Schraven, D.; Zhan, C.; Weijnen, M. Sustainable-smart-resilient-low carbon-eco-knowledge cities; making sense of a multitude of concepts promoting sustainable urbanization. J. Clean. Prod. 2015, 109, 25-38. [CrossRef]

15. Schandl, H.; Hatfield-Dodds, S.; Wiedmann, T.; Geschke, A.; Cai, Y.; West, J.; Newth, D.; Baynes, T.; Lenzen, M.; Owen, A. Decoupling global environmental pressure and economic growth: Scenarios for energy use, materials use and carbon emissions. J. Clean. Prod. 2016, 132, 45-56. [CrossRef] 
16. Ivanova, D.; Stadler, K.; Steen-Olsen, K.; Wood, R.; Vita, G.; Tukker, A.; Hertwich, E.G. Environmental impact assessment of household consumption. J. Ind. Ecol. 2016, 20, 526-536. [CrossRef]

17. Schandl, H.; Fischer-Kowalski, M.; West, J.; Giljum, S.; Dittrich, M.; Eisenmenger, N.; Geschke, A.; Lieber, M.; Wieland, H.; Schaffartzik, A. Global material flows and resource productivity: Forty years of evidence. J. Ind. Ecol. 2018, 22, 827-838. [CrossRef]

18. Tukker, A.; Jansen, B. Environmental impacts of products: A detailed review of studies. J. Ind. Ecol. 2006, 10, 159-182. [CrossRef]

19. Malik, K.; Rahman, S.M.; Khondaker, A.N.; Abubakar, I.R.; Aina, Y.A.; Hasan, M.A. Renewable energy utilization to promote sustainability in GCC countries: Policies, drivers, and barriers. Environ. Sci. Pollut. Res. 2019, 26, 20798-20814. [CrossRef] [PubMed]

20. Pan, S.-Y.; Gao, M.; Kim, H.; Shah, K.J.; Pei, S.-L.; Chiang, P.-C. Advances and challenges in sustainable tourism toward a green economy. Sci. Total Environ. 2018, 635, 452-469. [CrossRef] [PubMed]

21. Schaffartzik, A.; Duro, J.A.; Krausmann, F. Global appropriation of resources causes high international material inequalityGrowth is not the solution. Ecol. Econ. 2019, 163, 9-19. [CrossRef]

22. Arranz, A.M. Lessons from the past for sustainability transitions? A meta-analysis of socio-technical studies. Glob. Environ. Chang. 2017, 44, 125-143. [CrossRef]

23. Sarkodie, S.A. Causal effect of environmental factors, economic indicators and domestic material consumption using frequency domain causality test. Sci. Total Environ. 2020, 736, 139602. [CrossRef]

24. Canas, A.; Ferrao, P.; Conceicao, P. A new environmental Kuznets curve? Relationship between direct material input and income per capita: Evidence from industrialised countries. Ecol. Econ. 2003, 46, 217-229. [CrossRef]

25. Bringezu, S.; Schütz, H.; Steger, S.; Baudisch, J. International comparison of resource use and its relation to economic growth: The development of total material requirement, direct material inputs and hidden flows and the structure of TMR. Ecol. Econ. 2004, 51, 97-124. [CrossRef]

26. Vehmas, J.; Luukkanen, J.; Kaivo-Oja, J. Linking analyses and environmental Kuznets curves for aggregated material flows in the EU. J. Clean. Prod. 2007, 15, 1662-1673. [CrossRef]

27. Steinberger, J.K.; Krausmann, F.; Getzner, M.; Schandl, H.; West, J. Development and dematerialization: An international study. PLoS ONE 2013, 8, e70385. [CrossRef]

28. Steinberger, J.K.; Krausmann, F.; Eisenmenger, N. Global patterns of materials use: A socioeconomic and geophysical analysis. Ecol. Econ. 2010, 69, 1148-1158. [CrossRef]

29. Steger, S.; Bleischwitz, R. Drivers for the use of materials across countries. J. Clean. Prod. 2011, 19, 816-826. [CrossRef]

30. Schaffartzik, A.; Mayer, A.; Gingrich, S.; Eisenmenger, N.; Loy, C.; Krausmann, F. The global metabolic transition: Regional patterns and trends of global material flows, 1950-2010. Glob. Environ. Chang. 2014, 26, 87-97. [CrossRef] [PubMed]

31. Giljum, S.; Dittrich, M.; Lieber, M.; Lutter, S. Global patterns of material flows and their socio-economic and environmental implications: A MFA study on all countries world-wide from 1980 to 2009. Resources 2014, 3, 319-339. [CrossRef]

32. Wiedmann, T.O.; Schandl, H.; Lenzen, M.; Moran, D.; Suh, S.; West, J.; Kanemoto, K. The material footprint of nations. Proc. Natl. Acad. Sci. USA 2015, 112, 6271-6276. [CrossRef] [PubMed]

33. Dittrich, M.; Giljum, S.; Lutter, S.; Polzin, C. Green Economies around the World. Implications of Resource Use for Development and the Environment; SERI: Vienna, Austria, 2012.

34. Piña, W.H.A.; Martínez, C.I.P. Urban material flow analysis: An approach for Bogotá, Colombia. Ecol. Indic. 2014, 42, 32-42. [CrossRef]

35. Decker, E.H.; Elliott, S.; Smith, F.A.; Blake, D.R.; Rowland, F.S. Energy and material flow through the urban ecosystem. Annu. Rev. Energy Environ. 2000, 25, 685-740. [CrossRef]

36. Li, Y.; Zhang, Y.; Yu, X. Urban weight and its driving forces: A case study of Beijing. Sci. Total Environ. 2019, 658, 590-601. [CrossRef]

37. Liu, W.; Chang, A.C.; Chen, W.; Zhou, W.; Feng, Q. A framework for the urban eco-metabolism model-Linking metabolic processes to spatial patterns. J. Clean. Prod. 2017, 165, 168-176. [CrossRef]

38. Moore, J.; Kissinger, M.; Rees, W.E. An urban metabolism and ecological footprint assessment of Metro Vancouver. J. Environ. Manag. 2013, 124, 51-61. [CrossRef]

39. Sahely, H.R.; Dudding, S.; Kennedy, C.A. Estimating the urban metabolism of Canadian cities: Greater Toronto Area case study. Can. J. Civ. Eng. 2003, 30, 468-483. [CrossRef]

40. Barles, S. Urban metabolism of Paris and its region. J. Ind. Ecol. 2009, 13, 898-913. [CrossRef]

41. Pata, U.K. Renewable energy consumption, urbanization, financial development, income and $\mathrm{CO}_{2}$ emissions in Turkey: Testing EKC hypothesis with structural breaks. J. Clean. Prod. 2018, 187, 770-779. [CrossRef]

42. He, L.; Zha, J.; Loo, H.A. How to improve tourism energy efficiency to achieve sustainable tourism: Evidence from China. Curr. Issues Tour. 2020, 23. [CrossRef]

43. Alola, A.A.; Eluwole, K.K.; Alola, U.V.; Lasisi, T.T.; Avci, T. Environmental quality and energy import dynamics: The tourism perspective of the coastline Mediterranean countries (CMCs). Manag. Environ. Qual. 2019. [CrossRef]

44. Adedoyin, F.F.; Bekun, F.V. Modelling the interaction between tourism, energy consumption, pollutant emissions and urbanization: Renewed evidence from panel VAR. Environ. Sci. Pollut. Res. 2020, 27, 38881-38900. [CrossRef] 
45. Akadiri, S.S.; Lasisi, T.T.; Uzuner, G.; Akadiri, A.C. Examining the causal impacts of tourism, globalization, economic growth and carbon emissions in tourism island territories: Bootstrap panel Granger causality analysis. Curr. Issues Tour. 2020, $23,470-484$. [CrossRef]

46. Uzuner, G.; Akadiri, S.S.; Lasisi, T.T. The asymmetric relationship between globalization, tourism, $\mathrm{CO}_{2}$ emissions and economic growth in Turkey: Implications for environmental policy making. Environ. Sci. Pollut. Res. 2020, 27, 32742-32753. [CrossRef]

47. Eluwole, K.K.; Akadiri, S.S.; Alola, A.A.; Etokakpan, M.U. Does the interaction between growth determinants a drive for global environmental sustainability? Evidence from world top 10 pollutant emissions countries. Sci. Total Environ. 2020, 705, 135972. [CrossRef]

48. Giljum, C.P.S.; Dittrich, S.B.M. Resource Use and Resource Efficiency in Emerging Economies: A Pilot Study on Trends over the Past 25 Years; Sustainable Europe Research Institute: Vienna, Austria, 2011.

49. Grübler, A.; Nakićenović, N.; Victor, D.G. Dynamics of energy technologies and global change. Energy Policy 1999, 27, 247-280. [CrossRef]

50. Apergis, N.; Dincer, O.C.; Payne, J.E. The relationship between corruption and income inequality in US states: Evidence from a panel cointegration and error correction model. Public Choice 2010, 145, 125-135. [CrossRef]

51. Apergis, N.; Payne, J.E. Renewable energy consumption and economic growth: Evidence from a panel of OECD countries. Energy Policy 2010, 38, 656-660. [CrossRef]

52. Ozturk, I.; Aslan, A.; Kalyoncu, H. Energy consumption and economic growth relationship: Evidence from panel data for low and middle income countries. Energy Policy 2010, 38, 4422-4428. [CrossRef]

53. Ozturk, I.; Acaravci, A. The long-run and causal analysis of energy, growth, openness and financial development on carbon emissions in Turkey. Energy Econ. 2013, 36, 262-267. [CrossRef]

54. Uddin, M.M.M. What are the dynamic links between agriculture and manufacturing growth and environmental degradation? Evidence from different panel income countries. Environ. Sustain. Indic. 2020, 7, 100041. [CrossRef]

55. Dietz, T.; Rosa, E.A.; York, R. Driving the human ecological footprint. Front. Ecol. Environ. 2007, 5, 13-18. [CrossRef]

56. Wiedmann, T.O.; Schandl, H.; Moran, D. The footprint of using metals: New metrics of consumption and productivity. Environ. Econ. Policy Stud. 2015, 17, 369-388. [CrossRef]

57. Baynes, T.M.; Musango, J.K. Estimating current and future global urban domestic material consumption. Environ. Res. Lett. 2018, 13, 65012. [CrossRef]

58. Asongu, S.A.; Odhiambo, N.M. How enhancing information and communication technology has affected inequality in Africa for sustainable development: An empirical investigation. Sustain. Dev. 2019, 27, 647-656. [CrossRef]

59. Asongu, S.A.; Odhiambo, N.M. Basic formal education quality, information technology, and inclusive human development in sub-Saharan Africa. Sustain. Dev. 2019, 27, 419-428. [CrossRef]

60. Mosteller, F.; Tukey, J.W. Data Analysis and Regression: A Second Course in Statistics; Addison-Wesley: Boston, MA, USA, 1977.

61. Koenker, R.; Bassett, G., Jr. Regression quantiles. Econom. J. Econom. Soc. 1978, 46, 33-50. [CrossRef]

62. Phillips, P.C.B.; Hansen, B.E. Statistical inference in instrumental variables regression with I (1) processes. Rev. Econ. Stud. 1990, 57, 99-125. [CrossRef]

63. Bianchi, M.; Tapia, C.; del Valle, I. Monitoring domestic material consumption at lower territorial levels: A novel data downscaling method. J. Ind. Ecol. 2020, 24, 1074-1087. [CrossRef]

64. Marco, V.; Baggio, R. Italian tourism intermediaries: A social network analysis exploration. Curr. Issues Tour. 2021, 24, 1270-1283. 